\title{
Islam yang Dinamis di Nusantara
}

DOI 10.18196/AIIJIS.2017.0076.277-282

\section{TEGUH SUYONO ARIFIN}

Mahasiswa Pasca Sarjana Universitas Muhammadiyah Yogyakarta

$\begin{array}{ll}\text { Judul } & \text { : Sejarah Islam Nusantara } \\ \text { Penulis } & \text { : Ustadz Rizem Aizid } \\ \text { Penerbit } & \text { : DIVA Press } \\ \text { Kota } & : \text { Yogyakarta } \\ \text { Tahun } & : 2016 \\ \text { Halaman } & : 396 \\ \text { ISBN } & : 978-602-391-299-5\end{array}$

Dakwah Islam dari Makkah al Mukaromah melewati rentang waktu sampai ke kepulauan Nusantara telah menghasilkan kajian penelitian yang banyak, tetapi selalu menarik untuk dipelajari, dikaji, sehingga muncul lagi buku hasil kajian baru masuknya Islam ke Nusantara, tidak jemu-jemu mempelajari sejarah nusantara dan akan memperkaya pemahaman sejarah yang selalu menemukan hal-hal baru yang menarik yang berbeda dari buku-buku sejarah lainnya.

Buku Sejarah Islam Nusantara menyajikan sudut pandang Islam di Nusantara, tidak hanya wilayah Indonesia tetapi juga negera tetangga, Malaysia, Singapura, dan Pilipina, perkembangan Islam di Nusantara tidak dapat dilepaskan dari peran negara-negara tetangga yang dalam hubungan Islam selalu ada hubungan timbal balik dan saling mempengaruhi dalam dakwah Islam. Penyebaran Islam ke berbagai tempat di seluruh penjuru bumi dibawa oleh para pedagang muslim, termasuk di Nusantara. Islam menyebar dengan damai, diterima dengan baik oleh pribumi melalui berbagai jalan dakwah yang menyejukkan, seperti perkawinan, akulturasi budaya, perdagangan dan lain sebagainya.

Buku ini menyajikan penyampaian isi yang menarik yang diawali dengan apa yang menjadi latar belakang penulisan buku dan sistematika penulisan yang terdiri dari tiga bagian, bagian 1 awal mula masuknya Islam ke 
Nusantara, bagian 2 sejarah penyebaran Islam di Nusantara, bagian 3 peninggalan-peninggalan Islam di Nusantara, pembagian menjadi 3 bagian ini menarik karena mengingatkan kembali bahwa awal mula Islam masuk ke Nusantara melalui jalan yang damai tanpa ada kekerasan, maupun tipu muslihat, Islam menyebar ke Nusantara diawali dari Sumatera, dari Sumateralah Islam sampai ke Kalimantan, Jawa, Sulawesi, Nusantenggara, Indonesia timur bahkan sampai ke Philipina selatan. Penjagaan warisan peninggalan Islam dari masa lalu tetap terjaga dengan baik sampai sekarang, seperti Masjid, Istana, adat budaya, seni sastra.

Bagian satu dari buku ini adalah Awal-mula masuknya Islam ke Nusantara, bagian ini akan mengantarkan kita pemahaman awal-mula masiknya Islam ke Nusantara, mulai dari pembawanya, waktu, jalur, dan media yang digunakan Islam masuk ke Nusantara dan menyebar ke sebagian besar Nusantara hingga menjadi agama dengan penganut terbesar saat ini tentu saja tidaklah mudah, tetapi melalui proses yang sangat panjang dan militan. Islam masuk ke Nusantara berawal dari wilayah pesisir yang kemudian bergerak ke pedalaman ini, penyebaran Islam diambil alih dan dilakukan oleh ulama. Masuknya Islam ke Nusantara ada 4 teori yang mendasarinya yang masing-masing mempunyai pendukung dan kelemahannya, Teori Gujarat, Teori Makkah, Teori Persia, Teori Tiongkok, setiap teori tersebut saling melengkapi teori yang lain, betapa luas masuknya Islam ke Nusantara dari berbagai arah dan inilah yang memperkaya Islam Nusantara. Teori awal mula masuknya Islam ke Nusantara ada 3 pada abad ke 7, abad ke 11, abad ke 13, pada abad ke 7 Islam sudah mulai masuk ke Nusantara, tetapi belum berkembang, abad 11 mulai ada pemukiman Muslim di pelabuhan sebagai pusat perdagangan, abad ke 13 mulai ada kerajaan Islam yang pertama yaitu di samudera pasai.

Bagian satu dari buku Islam di Nusantara bab II membahas tentang Jalur-jalur masuknya Islam ke Nusantara, jalur perdagangan, perkawinan, struktur sosial, pendidikan, seni dan budaya, ajaran tasawuf. Dakwah Islam dapat masuk ke masyarakat dari berbagai jalur yang saling melengkapi membuktikan bahwa Islam merupakan agama yang mudah diterima masyarakat

Bagian kedua dari buku ini adalah Sejarah Penyebaran Islam di Nusantara, pada bab pertama tentang penyebaran Islam di Sumatera, menarik untuk dikaji bahwa Islam masuk ke Nusantara yang pertama kali 
adalah pulau Sumatera tepatnya di Barus, Tapanuli Tengah, karena Barus merupakan pusat dagang internasional walaupun Islam sudah masuk ke Barus tetapi tidak mengalami perkembangan yang signifikan. Setelah dari Barus perkembangan Islam selanjutnya di Sumatera bagian utara, Samudra Pasai pada abad ke 13 dengan adanya makam Sultan Malik as-Saleh, penyebaran Islam kemudian ke Aceh, kemudian ke Sumatera Barat tanah Minangkabau, Mandailing, Sumatera selatan, menariknya Malaka dimasukkan ke perkembangan Islam dari Sumatera, termasuk Tumasik (Singapura).

Bagian kedua dari buku ini adalah Sejarah Penyebaran Islam di Nusantara, pada bab kedua tentang sejarah penyebaran Islam di Jawa, Jawa adalah yang kedua memperoleh cahaya Islam, sekitar abad ke 10 Islam sudah ada di Jawa dibuktikan dengan makam Fatimah binti Maemun di Leran Jawa Timur, tetapi baru berkembang mulai abad ke 13, penyebaran Islam di Jawa berkembang pesat setelah berdirinya kesultanan Demak Bintoro oleh Raden Pattah dibantu oleh para Wali Sanga, dakwah selanjutnya dilakukan oleh ulama yang mendapat sebutan Wali Sanga, penyebaran Islam pertama di pesisir utara Jawa setelah masyarakat pesisir mengikuti Islam barulah para ulama Wali Sanga menyebarkan Islam ke ke pedalaman selatan Jawa, masyarakat Jawa memeluk Islam tanpa ada kekerasan ataupun peperangan.

Bagian kedua dari buku ini adalah Sejarah Penyebaran Islam di Nusantara, pada bab ketiga tentang penyebaran Islam di Sulawesi. Rakyat Sulawesi mengenal Islam melalui para juru dakwah dari tanah Jawa peran Wali Sanga sangat berperan yaitu melalui Sunan Giri di Gresik banyak para santrinya dari Sulawesi dan Indonesia timur dari merekalah Islam menyebar ke Sulawesi. Juru dakwah dari tanah sumatera juga sangat berperan dalam mengislamkan sulawesi mereka adalah Dato ri Tiro, Dato ri Bandang, Dato Patimang, perkembangan pesat Islam di Sulawesi pada masa kerajaan Gowa-Tallo dipimpin oleh Sultan Alauddin yang diikuti oleh kerajaan taklukannya.

Bagian kedua dari buku ini adalah Sejarah Penyebaran Islam di Nusantara, pada bab keempat tentang penyebaran Islam di Kalimantan. Penyebaran Islam di Kalimantan dapat dibagi menjadi tiga yakni dakwah Islam di kalimantan Barat yang dilakukan oleh ulama dari Sumatera dan Hadramaut, dakwah Islam di kalimantan selatan oleh Wali Sanga dan murid Wali Sanga dari Jawa, dakwah Islam di Kalimantan Timur oleh Dato 
ri Bandang dan Tuan Tunggang Parangan.dari Sulawesi Selatan, menariknya Islam sampai ke Kalimantan melalui 3 daerah berbeda walaupun tidak ada kerjasama diantara mereka tetapi tujuan sama yaitu sampainya dakwah Islam di bumi kalimantan.

Bagian kedua dari buku ini adalah Sejarah Penyebaran Islam di Nusantara, pada bab kelima tentang penyebaran Islam di Maluku dan sekitarnya. Dakwah Islam sampai ke Maluku dibawa oleh para pedagang dari Malaka, Sulawesi, Jawa, serta dari Jawa peranan pesantren Sunan Giri yang menjadi pusat perguruan Islam, yang para santrinya dari Indonesia Timur setelah mereka kembali ke daerah asalnya maka ikut menyebarkan Islam di daerah asalnya, ada dua kerajaan Islam di Maluku yang sangat besar pengaruhnya sehingga Islam dapat menyebar ke seluruh Maluku, kerajaan itu adalah Ternate dan Tidore yang sampai sekarang masih ada dan diakui oleh masyarakat.

Bagian kedua dari buku ini adalah Sejarah Penyebaran Islam di Nusantara, pada bab keenam tentang penyebaran Islam di wilayah timur Nusantara, yang diamaksudkan disini ialah, Bali, Nusa Tenggara Barat, dan Nusa Tenggara Timur.Bali juga menerima dakwah Islam walaupun sudah lama sekitar abad 14 tetapi perkembangan Islam di Bali tidak menggembirakan dikarenakan penyebaran Islam di Bali tidak terstruktur dengan rapi antara satu ulama dengan ulama lainnya tidak terjalin komunikasi yang baik. Dakwah Islam di Lombok dilakukan oleh Sunan Prapen, putra Sunan Ratu Giri dapat dikatakan bahwa dakwah di Lombok berhasil sekarang mayoritas masyarakat Lombok adalah Muslim. Dakwah Islam di Nusa Tenggara Timur dilakukan oleh para pedagang dari Palembang antara lain oleh Syihabudin bin Salman al-Farisi atau Sultan Menanga di pulau Solor yang kemudian menyebar ke seluruh Nusa Tenggra Timur.

Bagian kedua dari buku ini adalah Sejarah Penyebaran Islam di Nusantara, pada bab ketujuh tentang sebab-sebab Islam cepat diterima di Nusantara. Dalam dakwah ulama dan mubaligh menerapkan cara-cara yang jitu dan mudah sehingga Islam mudah diterima oleh masyarakat. Seperti untuk memeluk agama Islam syaratnya sangat mudah dan murah, akulturasi budaya, tidak mengenal kasta, cara ibadah yang mudah, para penyebar Islam dapat diteladani, peran aktif para raja, disebarkan dengan jalan damai.dengan cara-cara yang damai tersebutlah Islam sampai ke Nusantara dan menjadi agama bagi mayoritas penduduk Nusantara. 
Bagian Ketiga Peninggalan-Peninggalan Islam di Nusantara pada bab pertama Peninggalan Islam berupa masjid. Masjid merupakan bagian penting dari masyarakat Muslim, setiap tempat yang menerima Islam pasti akan membangun masjid sebagai tempat ibadah dan identitas keislamannya, selain itu, beberapa peninggalan Islam berikut adalah masjid-masjid tertua, terbesar, dan terpopuler hingga sekarang. Masjidmasjid ini adalah Masjig Agung peninggalan Islam yang hingga kini menjadi bukti sejarah tertua dan terbesar Islam di Nusantara. Diantaranya adalah Masjid Agung Demak, Masjid Menara Kudus, Masjid Raya Baiturrahman Aceh, Masjid Raya Medan, Masjid Raya Banten, dan Masjid Agung Yogyakarta. Dan lain sebagainya.

Bagian Ketiga Peninggalan-Peninggalan Islam di Nusantara pada bab kedua Peninggalan Islam berupa Istana. Setiap kerajaan pastilah memiliki kompleks istana sebagai pusat pemerintahan dan tempat tinggal sultan. Istana-istana tersebut sebagian sudah hilang karena perjalanan waktu tetapi masih ada beberapa yang masih utuh dan dapat kita saksikan keberadaannya sebagai bukti bahwa Kerajaan-kerajaan Islam tersebut ada seperti Istana Maimun di Medan, Istana Siak Sri Inderapura di Riau, Keraton Cirebon, Keraton Surakarta, Keraton Yogyakarta, istana-istana tersebut masih utuh.

Bagian Ketiga Peninggalan-Peninggalan Islam di Nusantara pada bab ketiga Peninggalan Islam berupa Budaya, masuknya Islam dengan akulturasi budaya yang sampai sekarang budaya-budaya tersebut masih dilestarikan sebagai kekayaan warisan budaya bangsa, seperti upacara grebek besar di demak, pesta tabuik di Pariaman, Sumatera Barat, Budaya Dhuk Der di Semarang, Upacara Tumplak Wajik di Yogyakarta, Upacara Garebeg di Yogyakarta, Upacara Sekaten di Yogyakarta, upacara tradisional juga dilakaksanakn di daerah lain di Nusantara seperti Cirebon, Surakarta dan lain sebagainya.

Bagian Ketiga Peninggalan-Peninggalan Islam di Nusantara pada bab keempat Peninggalan Islam berupa seni sastra. Sastra merupakan unkapan perasaan seseorang yang dituangkan dalam bentuk tulisan yang indah. Sejak zaman pra Islam sampai datangnya Islam, seni sastra telah menjadi salah satu media yang digunakan oleh orang-orang kuno untuk menuangkan ekspresinya ke dalam bentuk tulisan. Tidak hanya itu, bahkan sastra di zaman Islam juga menjadi alat atau media dakwah yang cukup efektif. Berikut adalah lima jenis sastra yang menjadi warisan Islam di 
Nusantara. Kelima jenis sastra itu terbagi dalam lima kategori, yakni, hikayat, syair, suluk, dan sastra dalam kitab.

Kesimpulan akhir dari buku ini adalah buku ini sangat bagus untuk pemahaman sejarah Islam di Nusantara, pemaparan dari awal mula Islam Masuk ke Nusantara, Berkembangnya Islam, dan juga jejak peninggalan Islam di Nusantara yang menunjukkan, membuktikan bahwa Islam secara umum berkembang di Nusantara dengan jalan damai, ada beberapa kritik dan saran dalam buku ini antara lain dalam pembahasan mendalam tentang kerajaan Islam di Nusantara belum semuanya, mungkin terlalu luasnya cakupan maka pembahasan tiap-tiap daerah belum lengkap, perlu kajian lagi yang lebih lengkap seperti Pembahasan Islam di Sumatera, Islam di Jawa, Islam di Kalimantan, Islam di Sulawesi, Islam di Maluku, Islam di Nusa Tenggara, supaya kajian Islam lebih lengkap. 